\title{
Morphology and Molecular Analyses of a New Marine Ciliate, Arcuseries minima sp. nov. (Ciliophora: Urostylidae)
}

ZooBank: urn:Isid:zoobank.org:pub:97942DC9-41A9-431A-96FC-1D2F48A2CA67

\author{
Kang-San KIM ${ }^{1,2}$, Kyu-Seok CHAE ${ }^{1}$, Gi-Sik MIN ${ }^{1}$ \\ ${ }^{1}$ Department of Biological Sciences, Inha University, 100 Inha-ro, Nam-gu, Incheon 22212, South Korea \\ ${ }^{2}$ Restoration Assessment Team, Research Center for Endangered Species, National Institute of Ecology, Gomal-gil 23, Yernygong- \\ gon, Gegornagsangbark-do 36531, Korea
}

\begin{abstract}
A new marine urostylid ciliate, Arcuseries minima sp. nov., was discovered in South Korea. Morphological observations and molecular phylogenetic analyses based on small subunit ribosomal DNA (18S rDNA) sequences were used to describe the new species. Arcuseries minima is most similar to A. scutellum among all Arcuseries species, but differs in the following main characters: number of adoral membranelles (13-16 vs. 17 or 18), cortical granules (yellowish, clustered around cirri and dorsal bristles vs. colorless, irregularly scattered), number of macronuclear nodules (20-27 vs. 42-90), number of midventral cirri (5-10 vs. 12-14), and number of transverse cirri ( 5 or 6 vs. 8). The new species and A. scutellum differ from $A$. petzi and $A$. warreni in having smaller body size $(\leq 80 \mu \mathrm{m}$ vs. $\geq 80 \mu \mathrm{m})$ and fewer cirri: left marginal $(\leq 17$ vs. $\geq 18)$ and transverse $(\leq 8$ vs. $\geq 8)$ cirri. This relationship was supported by the phylogenetic tree, where these two groups were separated into two branches.
\end{abstract}

Key words: Marine ciliate, Arcuseries, phylogenetic analysis, urostylid, $18 \mathrm{~S}$ rDNA sequence.

\section{INTRODUCTION}

The genus Arcuseries Huang et al., 2014 is characterized by the following combination of featues: marine habitat; non-dorsomarginalian hypotrichs; roughly Ushaped-arranged transverse cirri; midventral complex composed of cirral pairs only; three frontal cirri; buccal cirrus, frontoterminal cirri, and pretransverse ventral cirri present; one right and one left marginal row; three bipolar dorsal kineties; caudal cirri lacking; undulating

Address for correspondence: Gi-Sik Min, Department of Biological Sciences, Inha University, 100 Inha-ro, Michuhol-gu, Incheon 22212, South Korea; Tel: +82-32-860-7692; Fax: +82-32-874-6737; Cell phone: +82-10-6219-0752; E-mail: gisikmin@gmail.com membranes roughly straight and more or less arranged in parallel; many macronuclear nodules (Berger 2006, Huang et al. 2014). In addition, Arcuseries is monophyletic and is supported by phylogenetic analyses (Huang et al. 2014). To date, three Arcuseries species, namely A. scutellum (Cohn, 1866) Huang et al., 2014, A. petzi (Shao et al., 2011) Huang et al., 2014 (type species), and $A$. warreni (Song and Wilbert, 1997) Huang et al., 2014, have been reported with morphological descriptions and molecular information (Berger 2006, Chen et al. 2010, Shao et al. 2011). Of the three Arcuseries species, two, A. petzi and $A$. warreni, have been recorded in Korean coastal waters (Kim et al. 2013, Kim and Min 2018). In the present study, we provide morphological descriptions and phylogenetic analyses of a new Arcuseries species. 


\section{MATERIALS AND METHODS}

\section{Sample collection and identification}

Specimens of Arcuseries minima were isolated from coastal waters in Jeju province, South Korea (salinity, 33\%; water temperature, $\left.27.1^{\circ} \mathrm{C}\right)\left(33^{\circ} 14^{\prime} 9.21^{\prime \prime} \mathrm{N} ; 1^{\circ} 6^{\circ} 35^{\prime} 55.38^{\prime \prime} \mathrm{E}\right)$ in August 2017. Seawater filtered with a $200 \mu \mathrm{m}$ nylon mesh was transferred to Petri dishes, and rice grains were added to enrich the growth of bacteria and bacteriovorous flagellates at room temperature $\left(18-22^{\circ} \mathrm{C}\right)$. Six months later, the new species was observed by chance. At that time, the salinity of the culture was over $50 \%$ o (exact salinity could not be measured). Also, no ciliates were present in the raw culture used for the present study, except for A. minima.

Living and protargol-stained specimens were observed under a stereo microscope (SZH10; Olympus, Tokyo, Japan) and a light microscope (DM2500; Leica, Wetzlar, Germany) at magnifications ranging from $\times 100$ to $\times 1,000$. Cell staining was performed according to Foissner (2014) (Procedure A). Line drawings of the specimens were conducted at magnification of $\times 400$ and $\times 1,000$, before being digitally drawn using Adobe Illustrator CS6 (Adobe, San Jose, CA, USA). In general, classification and terminology follow Berger (2006).

\section{DNA extraction, PCR amplification, and sequencing}

Cells were washed several times with distilled water to isolate single cells from the raw culture. Genomic DNA was then extracted using a REDExtract-N-Amp Tissue PCR Kit (Sigma-Aldrich Co., St. Louis, MO, USA) based on the manufacturer's protocol. Optimized PCR conditions were as follows: initial denaturation at $94^{\circ} \mathrm{C}$ for $2 \mathrm{~min} 30 \mathrm{~s}$, followed by 40 cycles of denaturation at $95^{\circ} \mathrm{C}$ for $30 \mathrm{~s}$, annealing at $56^{\circ} \mathrm{C}$ for $30 \mathrm{~s}$, and extension at $72^{\circ} \mathrm{C}$ for $3 \mathrm{~min}$, and a final extension at $65^{\circ} \mathrm{C}$ for $7 \mathrm{~min}$. The EukA (forward; $5^{\prime}-$ AAC CTG GTT GAT CCT GCC AGT-3') and the EukB (reverse; 5'-TGA TCC TGC AGG TTC ACC TAC-3') primers (Medlin et al. 1988) were used to amplify almost the entire $18 \mathrm{~S}$ rDNA sequence. Sequencing was performed using the ABI 3700 platform (Applied Biosystems, Foster city, CA, USA) using two internal primers, $18 \mathrm{~S}$ 300 (5'-CAT GGT AGT CCA ATA CAC TAC-3') and 18S+810 (5'GCC GGA ATA CAT TAG CAT GG-3').

\section{Phylogenetic analyses}

18S rDNA sequences determined in this study and those retrieved from GenBank were aligned using BioEdit (Hall 1999). jModelTest 2.1.7 (Darriba et al. 2012) was used to determine the appropriate DNA substitution model for maximum likelihood (ML) and Bayesian inference (BI) analyses and the TIM $2+\mathrm{I}(0.5490)+\mathrm{G}$ (0.4830) model was selected. For ML and BI analyses, the FASTA file was converted to NEXUS and PHYLIP files using MEGA 5.0 (Tamura et al. 2011). The ML analysis was conducted using PhyML version 3.1 and 1,000 bootstrap replicates (Guindon et al. 2010). BI assessment was conducted on MrBayes 3.2.2 (Ronquist et al. 2012) with a chain length of $1,000,000$ generations. Trees were sampled every 100 generations with a prior burn-in of $30 \%$. Sequence dissimilarity (absolute distance) was calculated using MEGA 5.0 (Tamura et al. 2011) using the pairwise distance option. Phylogenetic trees were visualized using FigTree v1.4.1 (http://tree.bio.ed.ac.uk/ spftware/figtree/, written by A. Rambaut). The pairwise distance and the number of nucleotides differences were calculated using MEGA 5.0 (Tamura et al. 2011).

\section{RESULTS}

\section{Arcuseries minima sp. nov.}

ZooBank: urn:lsid:zoobank.org:act:F17B7069-8B86-4A70-965442F85CDA0AC7

Diagnosis. Size in vivo 40-55 × 20-30 $\mu \mathrm{m}$; elliptical in shape, highly flexible, and contractile; 20-27 macronuclear nodules and 1-3 micronuclei; contractile vacuole lacking. Three type of cortical granules: (1) colorless, spherical shape, scattered, ca. $3 \mu \mathrm{m}$; (2) yellowish, clustered around cirri and dorsal bristles, ca. $1 \mu \mathrm{m}$; (3) colorless, scattered, ca. $0.5 \mu \mathrm{m}$. About 14 adoral membranelles; 3 frontal, 1 buccal, 2 frontoterminal, 5-10 midventral, 2 pretransverse, and 5 or 6 transverse cirri; 1 left (9-13 cirri) and 1 right (9-14 cirri) marginal row; 3 dorsal kineties.

Type locality. Seawater (salinity, 33\%o; water temperature, $27.1^{\circ} \mathrm{C}$ ) taken from Jeju province, South Korea $\left(33^{\circ} 14^{\prime} 9.21^{\prime \prime} \mathrm{N} ; 1^{\circ} 6^{\circ} 35^{\prime} 55.38^{\prime \prime} \mathrm{E}\right)$ in August 2017.

Type specimens. The slide (NIBRPR0000109740) containing the holotype specimen and two slides (NIBRPR0000109741, NIBRPR0000109742) including protargol-stained specimens have been deposited in the National Institute of Biological Resources (NIBR), Incheon, South Korea.

Etymology. The species-group name, minima, is the feminine version of the Latin adjective minimus (smallest) to indicate the small body size of the new species.

Description: Size in vivo 40-55 × 20-30 $\mu \mathrm{m}(\mathrm{n}=15)$, about $34 \times 11 \mu \mathrm{m}$ in protargol preparations; body highly flexible, contractile, oval to elongated elliptical, left and right cell margins slightly convex, both ends rounded, and cell color yellowish to grayish at low magnification (Figs. 1A, F, 2A-C, H). Macronuclear nodules size about $3.3 \times 1.9 \mu \mathrm{m}$ in protargol impregnation, $20-27$ in number; one to three micronuclei of size about $1.6 \times 1.4$ $\mu \mathrm{m}$ in protargol impregnation (Figs. 1G, $2 \mathrm{~J}$ ). Contractile vacuole lacking. Three types of cortical granules: type I (large-sized), colorless, spherical, about $3 \mu \mathrm{m}$ in size, irregularly distributed on dorsal surfaces; type II (medium-sized), yellowish, spherical, about $1 \mu \mathrm{m}$ in diameter, clustered around cirri and dorsal bristles; type III (small-sized), colorless, irregularly distributed on dorsal surfaces, less than $0.5 \mu \mathrm{m}$ in diameter (Figs. 


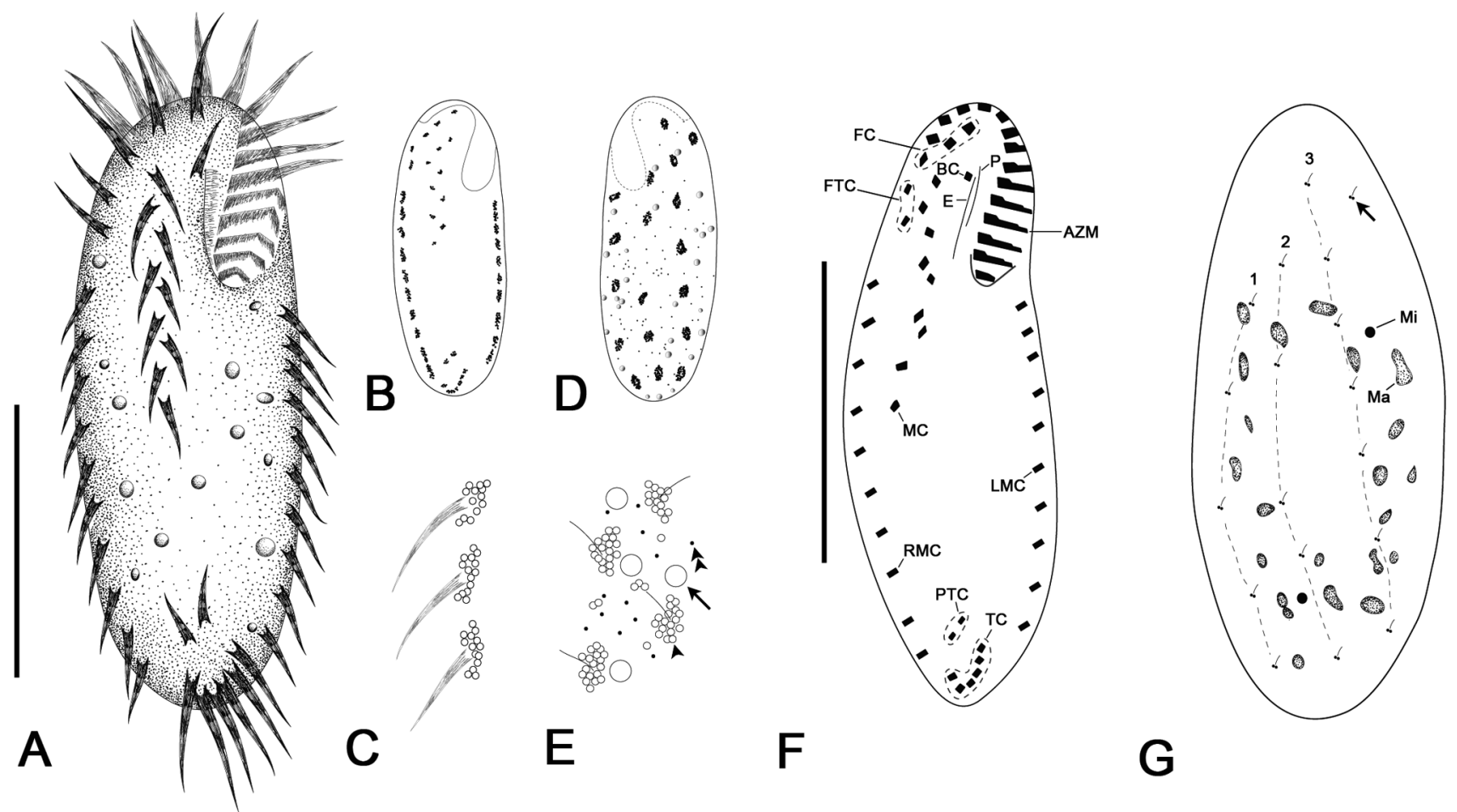

Fig. 1. Arcuseries minima sp. nov. in vivo (A-E) and after protargol impregnation (F, G). (A) Ventral view of a representative specimen. $(B, C)$ Cortical granulation in ventral surface. (D, E) Cortical granulation in dorsal surface, three types of cortical granules: the large (arrow), medium-sized (arrowhead), small (double arrowhead). (F) Ventral view of holotype specimen. (G) Dorsal view of a paratype specimen, arrow indicates a basal body. $\mathrm{AZM}=$ adoral zone of membranelles; $\mathrm{BC}=$ buccal cirrus; $\mathrm{E}=$ endoral; $\mathrm{FC}=$ frontal cirri; $\mathrm{FTC}=$ frontoterminal cirri; $\mathrm{LMC}=$ left marginal cirri; $\mathrm{Ma}=$ macronuclear nodules; $\mathrm{MC}=$ midventral cirri; $\mathrm{Mi}=$ micronuclei; $\mathrm{P}=$ paroral; $\mathrm{PTC}=$ pretransverse cirri; $\mathrm{RMC}=$ right marginal cirri; $\mathrm{TC}=$ transverse cirri; $1-3=$ dorsal kineties $1-3$. Scale bars: $20 \mu \mathrm{m}$.

1B-E, 2D-G). Cytoplasm colorless, with 3-5 $\mu \mathrm{m}$ sized food vacuoles. Feeds on bacteria.

Adoral zone of membranelles occupies about $31.5 \%$ of cell length in protargol preparations, base of the largest membranelles is about $3.5 \mu \mathrm{m}$ long, composed of 13-16 membranelles. Paroral and endoral membranes side by side, endoral membrane longer than paroral membrane (Figs. 1F, 2H, I). All cirri are relatively fine, generally $6-8 \mu \mathrm{m}$ long in vivo except frontal and transverse cirri. Three slightly enlarged frontal cirri about 10 $\mu \mathrm{m}$ in length, the rightmost cirrus located behind distal end of the adoral zone of membranelles. Two frontoterminal cirri behind the rightmost frontal cirrus, buccal cirrus on the anterior of endoral membrane, and two pretransverse cirri located ahead the transverse cirri. Five or six slightly enlarged transverse cirri, 10-12 $\mu \mathrm{m}$ in length. Midventral complex consists of two to five midventral pairs (five to ten cirri), arranged in a zigzag pattern, commencing near buccal cirrus and terminating on or above midbody. Two marginal rows, one left
(9-13 cirri) and one right (9-14 cirri) commencing behind the posterior end of the buccal field, and both rows non-confluent posteriorly (Figs. 1A, F, 2H, I).

Invariably three dorsal kineties, cilia about $3 \mu \mathrm{m}$ long in vivo: kineties 1 and 2 composed of four to six bristles, anteriorly shortened; almost bipolar kinety 3 composed of five to seven bristles. One pair of basal bodies located ahead of the right marginal cirral row (Figs. 1G, 2K).

Molecular analyses: The $18 \mathrm{~S}$ rDNA sequence of $\mathrm{Ar}$ cuseries minima sp. nov. is $1,598 \mathrm{bp}$ in length and has a GC content of $46.9 \%$. The sequence of $A$. minima was deposited in GenBank with accession number MK889350. BI and ML analyses produced similar topologies; thus, the ML tree was presented as our phylogenetic tree. In the gene tree, A. minima clusters with $A$. scutellum, and is a sister species to $A$. petzi and $A$. warreni (Fig. 3). In addition, $A$. minima shows a shorter pairwise distance with A. scutellum $(0.009,14$ or 15 differences in 1,598 nt) than with $A$. sp. $(0.018,29$ differences in $1,598 \mathrm{nt})$, 
Table 1. Morphometric data of Arcuseries minima sp. nov.

\begin{tabular}{|c|c|c|c|c|c|c|c|c|}
\hline Characteristic $^{\mathrm{a}}$ & Mean & M & SD & SE & $\mathrm{CV}$ & Min & Max & $N$ \\
\hline Body length & 34.0 & 33.0 & 4.8 & 1.0 & 14.2 & 28.0 & 40.0 & 22 \\
\hline Body width & 11.0 & 10.0 & 2.1 & 0.5 & 19.4 & 8.0 & 15.0 & 22 \\
\hline Length/width body portion & 3.1 & 3.0 & 0.5 & 0.1 & 16.1 & 2.5 & 4.1 & 22 \\
\hline Adoral zone of membranelles length & 11.7 & 12.0 & 1.0 & 0.2 & 8.8 & 10.0 & 14.0 & 22 \\
\hline Adoral membranelles, number & 14.2 & 14 & 1.0 & 0.2 & 7.1 & 13 & 16 & 22 \\
\hline Frontal cirri, number & 3.0 & 3 & 0.0 & 0.0 & 0.0 & 3 & 3 & 22 \\
\hline Buccal cirri, number & 1.0 & 1 & 0.0 & 0.0 & 0.0 & 1 & 1 & 22 \\
\hline Frontoterminal cirri, number & 2.0 & 2 & 0.0 & 0.0 & 0.0 & 2 & 2 & 22 \\
\hline Midventral cirri, number & 7.8 & 8 & 1.4 & 0.3 & 18.6 & 5 & 10 & 22 \\
\hline Pretransverse ventral cirri, number & 2.0 & 2 & 0.0 & 0.0 & 0.0 & 2 & 2 & 22 \\
\hline Transverse cirri, number & 5.6 & 6 & 0.5 & 0.1 & 8.7 & 5 & 6 & 22 \\
\hline Left marginal cirri, number & 11.2 & 11 & 1.2 & 0.3 & 11.0 & 9 & 13 & 22 \\
\hline Right marginal cirri, number & 11.2 & 11 & 1.3 & 0.3 & 11.6 & 9 & 14 & 22 \\
\hline Dorsal kineties, number & 3.0 & 3 & 0.0 & 0.0 & 0.0 & 3 & 3 & 11 \\
\hline Dikinetids on dorsal kinety 1 , number & 4.5 & 4 & 0.7 & 0.2 & 15.4 & 4 & 6 & 11 \\
\hline Dikinetids on dorsal kinety 2, number & 5.2 & 5 & 0.6 & 0.2 & 11.6 & 4 & 6 & 11 \\
\hline Dikinetids on dorsal kinety 3 , number & 6.6 & 7 & 0.7 & 0.2 & 10.2 & 5 & 7 & 11 \\
\hline Macronuclear nodules length & 3.3 & 3.0 & 1.2 & 0.3 & 37.9 & 1.5 & 5.0 & 22 \\
\hline Macronuclear nodules width & 1.9 & 1.5 & 1.2 & 0.2 & 60.0 & 1.0 & 4.5 & 22 \\
\hline Macronuclear nodules, number & 23.0 & 22.5 & 2.4 & 0.5 & 10.6 & 20 & 27 & 22 \\
\hline Micronucleus length & 1.6 & 1.5 & 0.5 & 0.1 & 28.6 & 1.0 & 2.5 & 22 \\
\hline Micronucleus width & 1.4 & 1.0 & 0.5 & 0.1 & 34.3 & 1.0 & 2.5 & 22 \\
\hline Micronucleus, number & 2.0 & 2 & 0.8 & 0.2 & 40.2 & 1 & 3 & 22 \\
\hline
\end{tabular}

All data based on randomly selected, protargol-stained specimens. CV, coefficient of variation in \%; M, median; Max, maximum; Mean, arithmetic mean; Min, minimum; $N$, number of specimens examined; SD, standard deviation; SE, standard error of the arithmetic mean.

${ }^{a}$ All data are based on protargol-stained specimens, measurements in $\mu \mathrm{m}$.

A.petzi $(0.024-0.027,38-43$ differences in $1,600 \mathrm{nt})$, and A. warreni $(0.026,42$ differences in 1,600 nt) (Table 3$)$.

\section{DISCUSSION}

Comparison with congeners: In the genus $\mathrm{ArCu}$ series, to date, three species, namely A. scutellum, A. petzi, and $A$. warreni, have been described (Huang et al. 2014). In addition, Holosticha sp., described by Wilbert and Song (2005), has similar morphological features to Arcuseries species in terms of body shape, size, nuclear apparatus, and ciliary structure; thus, in this section, we compare the new species to these four populations (Table 2).
Arcuseries petzi was recorded in Chinese and Korean coastal waters, and both populations are well described. However, because there is no significant difference between the two populations (Kim et al. 2013, Shao et al. 2011), the Chinese population (original) was compared with the new species. The Chinese population of $A$. petzi differs from A. minima sp. nov. in the following features: body length in vivo (85-105 $\mu \mathrm{m}$ vs. 35-55 $\mu \mathrm{m})$; number of macronuclear nodules (55-115 vs. 20-27); number of adoral membranelles (20-30 vs. 13-16); numbers of midventral (20-32 vs. 5-10), left marginal (18-32 vs. 9-13), right marginal (24-42 vs. 9-14), and transverse cirri (8-11 vs. five or six); dorsal bristles in kinety 1 (12, counted from illustration vs. four to six). These two species have three types of cortical granules; of these, the medium-sized granules differ 


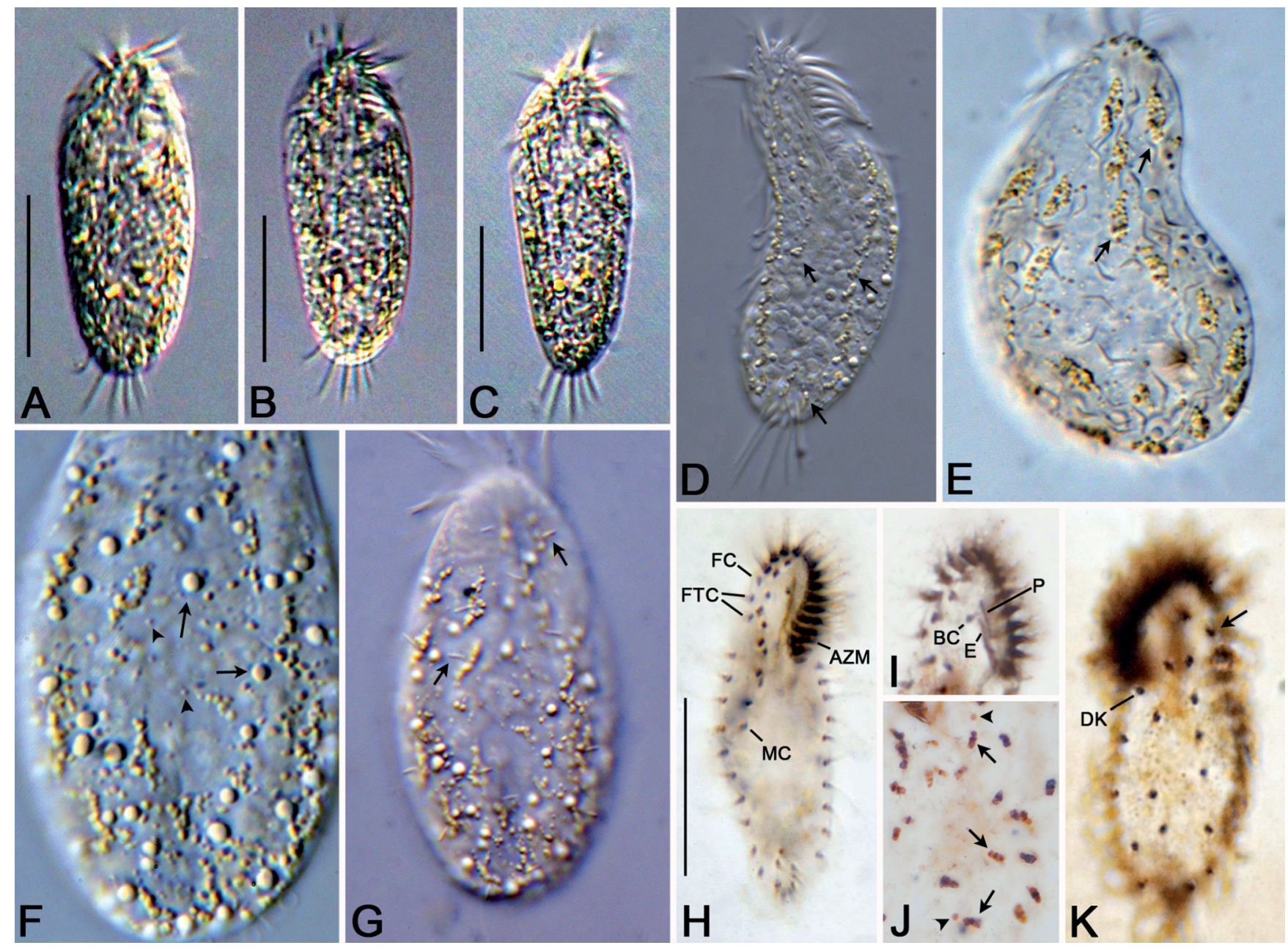

Fig. 2. Arcuseries minima sp. nov. in vivo. (A-G) and after protargol impregnation (H-K). (A-C) Ventral views showing body outline. (D) Cortical granulation in ventral surface, arrows indicate medium-sized cortical granules. (E) Cortical granulation in dorsal surface, arrows mark medium-sized cortical granules. (F) Arrows mark large cortical granules, arrowheads indicate small cortical granules. (G) Arrows indicate dorsal cilia. (H) Ventral view of the holotype specimen. (I) Ventral view of buccal field. (J) Arrows indicate macronuclear nodules, arrowheads mark micronuclei. (K) Dorsal view of a specimen, arrow indicates basal body pairs. AZM = adoral zone of membranelles; $\mathrm{BC}=$ buccal cirrus; $\mathrm{DK}=$ dorsal kineties $\mathrm{E}=$ endoral; $\mathrm{FC}=$ frontal cirri; $\mathrm{FTC}=$ frontoterminal cirri; $\mathrm{MC}=$ midventral cirri; $\mathrm{P}=$ paroral . Scale bars: $20 \mu \mathrm{m}$.

in color between species (dark in $A$. petzi vs. yellowish in A. minima) (Shao et al. 2011).

The Chinese population of Arcuseries warreni differs from $A$. minima as follows: body length in vivo (80-120 $\mu \mathrm{m}$ vs. $35-55 \mu \mathrm{m})$; number of macronuclear nodules (ca. 50 vs. 20-27); number of adoral membranelles (26-31 vs. 13-16); numbers of midventral (20-32 vs. 5-10), left marginal (22-27 vs. 9-13), right marginal (21-26 vs. 9-14), and transverse cirri (10-12 vs. five or six); dorsal bristles in kinety 1 (19, counted from illustration vs. four to six); erythrocyte-shaped granules and extrusomes (present vs. absent) (Song and Wilbert 1997). The Korean population of A. warreni can be distinguished from $A$. minima by the following features: body length in vivo $(70-100 \mu \mathrm{m}$ vs. 35-55 $\mu \mathrm{m})$; number of macronuclear nodules (43-60 vs. 20-27); number of adoral membranelles (28-30 vs. 13-16); numbers of midventral pair (seven to nine vs. two to five); left marginal (20-25 vs. 9-13), right marginal (20-27 vs. 9-14), and transverse cirri (10-12 vs. five or six); dorsal bristles in kinety 1 (14, counted from illustration vs. four to six). In addition, color of 


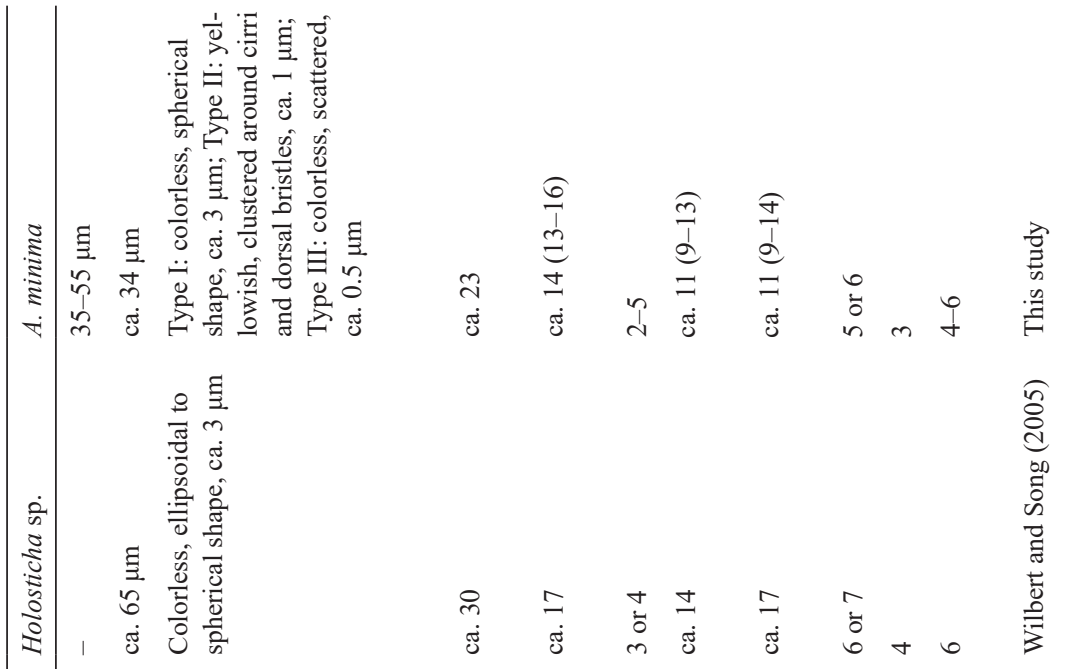

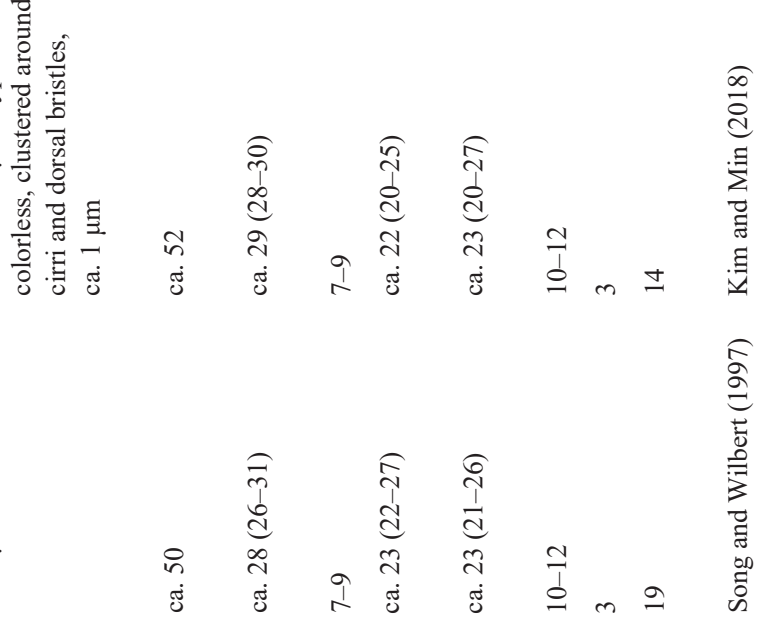

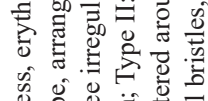

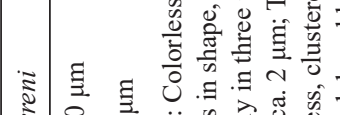

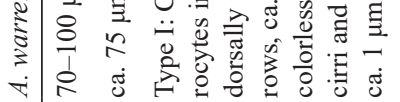

$\exists$

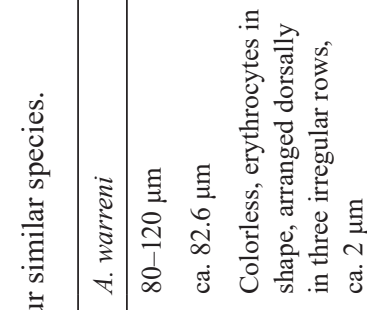

音

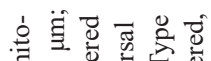

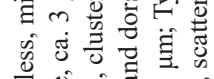

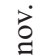

के

辛

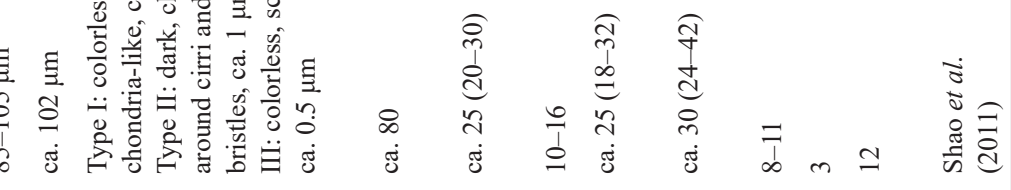

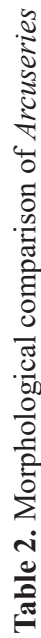

离

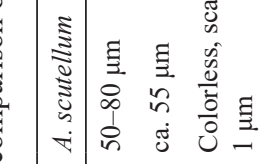

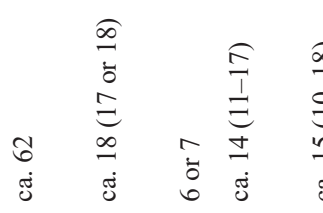

离

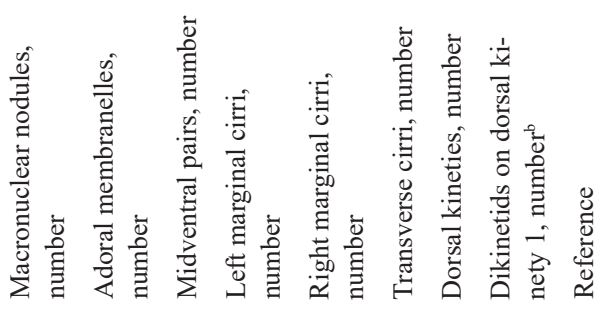

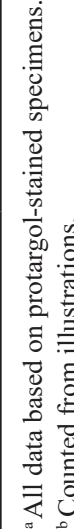




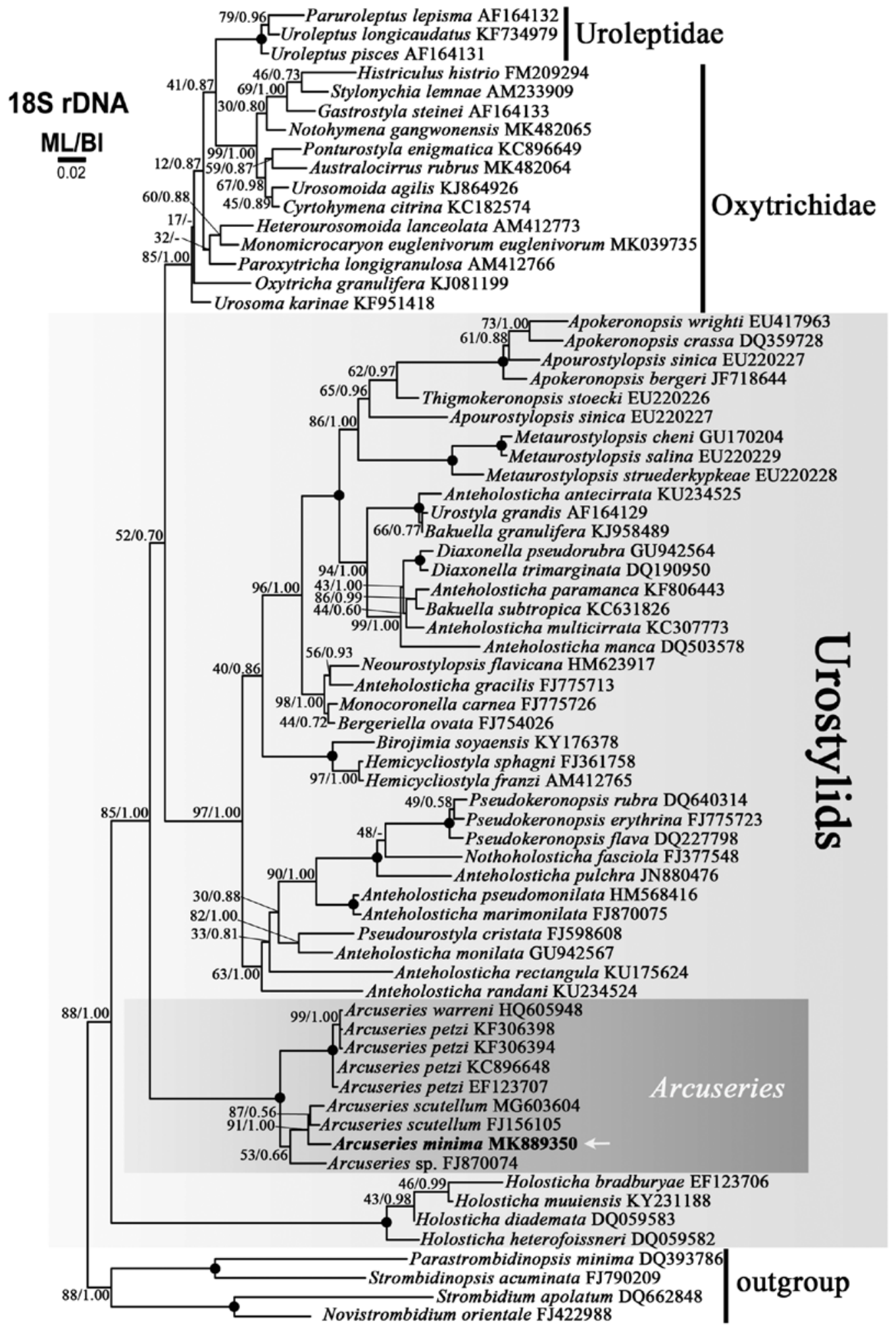

Fig. 3. Maximum likelihood and Bayesian inference analyses based on $18 \mathrm{~S}$ rDNA sequences. The new sequence provided in the present work is indicated in bold and by a white arrow. Numbers at nodes indicate the bootstrap values of ML out of 1,000 replicates and the posterior probability of BI. Fully supported (100/1.00) branches are marked with solid circles. The scale bar corresponds to 2 substitutions per 100 nucleotide positions. 


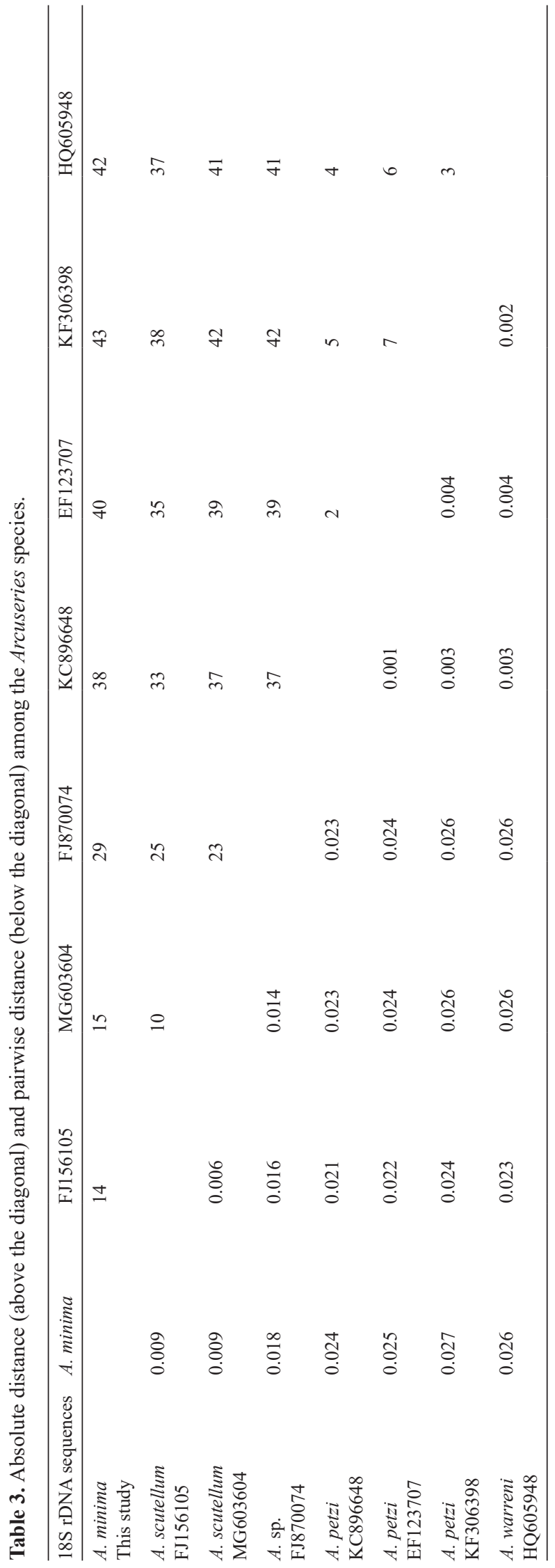

cortical granules (medium-sized) were different (colorless in A. warreni vs. yellowish in A. minima) (Kim and Min 2018).

Unlike the two species described above, Arcuseries scutellum has a small body size ( $50-80 \mu \mathrm{m}$ long in vivo) and is similar to A. minima. But $A$. scutellum differs from $A$. minima in number of macronuclear nodules (41-90 vs. 20-27); number of adoral membranelles (17 or 18 vs. 13-16); number of midventral pairs (six or seven vs. two to five); number of transverse cirri (eight vs. five or six); dorsal bristles in kinety 1 (eight, counted from illustration vs. four to six); distribution of medium-sized cortical granules (irregularly scattered vs. clustered around cirri and dorsal bristles) (Chen et al. 2010).

Holosticha sp., described by Wilbert and Song (2005), has only been studied based on stained specimens, and morphometric data were calculated based on average values. Thus, the available data is limited. Holosticha sp. differs from Arcuseries minima in the following features: body length in stained specimens (ca. $65 \mu \mathrm{m}$ vs. ca. $34 \mu \mathrm{m}, 28-40 \mu \mathrm{m}$ ); number of macronuclear nodules (ca. 30 vs. ca. 23, 20-27); number of adoral membranelles (ca. 17 vs. ca. 14, 13-16); number of left marginal (ca. 14 vs. ca. 11, 9-13), and right marginal (ca. 17 vs. ca. 11, 9-14) cirri; number of dorsal kineties (four vs. three). When comparing the average values, the values of the new species are lower than those of Holosticha sp. (Table 2). However, the range of values seems likely to overlap, except those for body length and number of dorsal kineties. In addition, the granules of Holosticha sp. are similar to the large-sized cortical granules of the new species. Thus, Holosticha sp. is considered to have a close relationship with Arcuseries, and molecular data from Holosticha $\mathrm{sp}$. is needed to clarify this assumption.

Phylogenetic analyses: In molecular analyses based on 18S rDNA sequences, the genus Arcuseries is monophyletic (Huang et al. 2014, Zhao et al. 2015). Arcuseries is morphologically very close to Anteholosticha but differs in terms of the arrangement of transverse cirri (U-shaped vs. J-shaped), number of dorsal kineties (invariably three vs. more than three), and molecular differences (the Arcuseries-clade is clearly separated from Anteholosticha clades) (Huang et al. 2014). Our tree also clearly showed Arcuseries as being monophyletic as in previous studies (Fig. 3). The new species was included in the Arcuseries clade (Fig. 3) and has transverse cirri arranged in U-shape and three dorsal kineties. In the gene tree, the new species clustered with 
A. scutellum (Fig. 3), and the difference in 18S rDNA sequences between these two species was the smallest of all the Arcuseries species (Table 3). As mentioned in the comparison subsection above, A. minima and $A$. scutellum displayed smaller body sizes when compared with $A$. petzi and A. warreni, and had fewer cirri. The gene tree also reflects these morphological differences by dividing these groups into two branches (Fig. 3).

Acknowledgements. This work was supported by a grant from the National Institute of Biological Resources (NIBR), funded by the Ministry of Environment (MOE) of the Republic of Korea (NIBR201902204).

\section{REFERENCES}

Berger H. (2006) Monograph of the Urostyloidea (Ciliophora, Hypotricha). Monogr. Biol. 85: 1-1303, i-Xv

Chen X. R., Gao S., Song W. B., Al-Rasheid K. A. S., Warren A., Gong J., et al. (2010) Parabirojimia multinucleata spec. nov and Anteholosticha scutellum (Cohn, 1866) Berger, 2003, marine ciliates (Ciliophora, Hypotrichida) from tropical waters in southern China, with notes on their small-subunit rRNA gene sequences. Int. J. Syst. Evol. Microbiol. 60: 234-243

Darriba D., Taboada G. L., Doallo R., Posada D. (2012) jModelTest 2: more models, new heuristics and parallel computing. Nat. Methods 9: 772

Foissner W. (2014) An update of 'basic light and scanning electron microscopic methods for taxonomic studies of ciliated protozoa'. Int. J. Syst. Evol. Microbiol. 64: 271-292

Guindon S., Dufayard J.-F., Lefort V., Anisimova M., Hordijk W., Gascuel O. (2010) New algorithms and methods to estimate maximum-likelihood phylogenies: assessing the performance of PhyML 3.0. Syst. Biol. 59: 307-321

Hall T. (1999) BioEdit: a user-friendly biological sequence alignment editor and analysis program for Windows 95/98/NT. Nucleic Acids Symp. Ser. 41: 95-98

Huang J., Chen Z. G., Song W. B., Berger H. (2014) Three-gene based phylogeny of the Urostyloidea (Protista, Ciliophora, Hy- potricha), with notes on classification of some core taxa. Mol. Phylogenet. Evol. 70: 337-347

Kim K. S., Jung J. H., Min G. S. (2013) New record of two marine ciliates (Ciliophora: Spirotrichea) in South Korea. Anim. Syst. Evol. Divers. 29: 144-151

Kim K. S., Min G. S. (2018) Brief morphological description of stichotrichid ciliates (Ciliophora: Stichotrichia) from Korea. $J$. Species Res. 7: 323-332

Medlin L., Elwood H. J., Stickel S., Sogin M. L. (1988) The characterization of enzymatically amplified eukaryotic 16S-like rRNA-coding regions. Gene 71: 491-499

Ronquist F., Teslenko M., Mark P. v. d., Ayres D. L., Darling A., Höhna S., et al. (2012) MrBayes 3.2: efficient bayesian phylogenetic inference and model choice across a large model space. Syst. Biol. 61: 539-542

Shao C., Gao F., Hu X., Al-Rasheid K. A., Warren A. (2011) Ontogenesis and molecular phylogeny of a new marine urostylid ciliate, Anteholosticha petzi n. sp. (Ciliophora, Urostylida). J. Eukaryot. Microbiol. 58: 254-265

Song W. B., Wilbert N. (1997) Morphological studies on some free living ciliates (Ciliophora: Heterotrichida, Hypotrichida) from marine biotopes in Qingdao, China, with descriptions of three new species: Holosticha warreni nov. spec., Tachysoma ovata nov. spec. and T. dragescoi nov. spec. Europ. J. Protistol. 33: $48-62$

Tamura K., Peterson D., Peterson N., Stecher G., Nei M., Kumar S. (2011) MEGA5: Molecular evolutionary genetics analysis using maximum likelihood, evolutionary distance, and maximum parsimony methods. Mol. Biol. Evol. 28: 2731-2739

Wilbert N., Song W. (2005) New contributions to the marine benthic ciliates from the Antarctic area, including description of seven new species (Protozoa, Ciliophora). J. Nat. Hist. 39: 935-973

Zhao X., Gao S., Fan Y., Strueder-Kypke M., Huang J. (2015) Phylogenetic framework of the systematically confused Anteholosticha-Holosticha complex (Ciliophora, Hypotrichia) based on multigene analysis. Mol. Phylogenet. Evol. 91: 238-247

Received on $17^{\text {th }}$ April, 2019; revised on $17^{\text {th }}$ May, 2019; accepted on $5^{\text {th }}$ July, 2019 